\title{
KOMPOSISI KIMIA, AKTIVITAS ANTIBAKTERI, DAN POTENSI UNTUK KEMASAN AKTIF DARI BEBERAPA MINYAK ATSIRI TANAMAN REMPAH INDONESIA
}

\author{
Retno Yunilawati ${ }^{1,2}$, Windri Handayani ${ }^{3}$, Dwinna Rahmi ${ }^{2}$, Aminah $^{4}$, Cuk Imawan ${ }^{1}$ \\ ${ }^{1}$ Departemen Fisika, Fakultas Matematika dan IImu Pengetahuan Alam, Universitas Indonesia, \\ Kampus Depok, Indonesia 16424 \\ ${ }^{2}$ Balai Besar Kimia dan Kemasan, Kementerian Perindustrian RI \\ Jl. Balai Kimia I Pekayon, Pasar Rebo, Jakarta Timur \\ ${ }^{3}$ Departemen Biologi, Fakultas Matematika dan Ilmu Pengetahuan Alam, Universitas Indonesia, \\ Kampus Depok, Indonesia 16424 \\ ${ }^{4}$ Departemen Kimia, Fakultas Matematika dan Ilmu Pengetahuan Alam, Universitas Indonesia, \\ Kampus Depok, Indonesia 16424
}

E-mail: cuk.imawan@sci.ui.ac.id

Received : 23 Desember 2020; revised : 23 Februari 2021; accepted : 23 Maret 2021

\begin{abstract}
ABSTRAK
KOMPOSISI KIMIA, AKTIVITAS ANTIBAKTERI, DAN POTENSI UNTUK KEMASAN AKTIF BEBERAPA MINYAK ATSIRI DARI TANAMAN REMPAH INDONESIA. Penelitian ini bertujuan untuk mengetahui komposisi kimia dan aktifitas antibakteri dari 6 jenis minyak atsiri Indoensia. Minyak atsiri tersebut adalah minyak ketumbar, minyak bunga cengkeh, minyak sereh dapur, minyak kulit jeruk purut, minyak kayu manis, dan minyak kapulaga. Penelitian dilakukan dalam dua tahap yaitu karakterisasi minyak atsiri menggunakan Gas Chromatography Mass Spectrometer (GC-MS) dan penentuan aktivitas antibakteri dari masing-masing minyak atsiri dengan bakteri gram positif Staphylococcus aureus NBRC 100910 dan bakteri gram negatif Escherichia coli NBRC 3301. Aktivitas antibakteri dinyatakan sebagai diameter zona hambat yang terbentuk pada saat pengujian. Minyak ketumbar, minyak sereh dapur dan minyak kayu manis memiliki aktivitas antibakteri yang kuat terhadap E. coli NBRC 330 dan S.aureus NBRC 100910 dengan diameter zona hambat pada E. coli NBRC 330 masing-masing sebesar $24 \mathrm{~mm}, 47 \mathrm{~mm}$ dan $34 \mathrm{~mm}$; dan pada S.aureus NBRC 100910 masing masing sebesar $22 \mathrm{~mm}, 25 \mathrm{~mm}$ dan $35 \mathrm{~mm}$. Minyak bunga cengkeh memiliki aktivitas antibakteri dengan tingkat sedang pada E. coli NBRC $330(19 \mathrm{~mm})$ dan kuat pada S.aureus NBRC $100910(28 \mathrm{~cm})$. Minyak kapulaga menunjukkan aktivitas antibakteri dengan tingkat sedang terhadap dua bakeri tersebut dengan diameter zona hambat $14 \mathrm{~mm}$ untuk E. coli NBRC 330 dan $12 \mathrm{~mm}$ untuk S.aureus NBRC 100910. Minyak kulit jeruk purut hanya memiliki aktivitas antibakteri terhadap S.aureus NBRC 100910 dengan diameter zona hambat sebesar 22 mm. Minyak ketumbar, minyak sereh dapur, dan minyak kayu manis berpotensi besar untuk diaplikasikan dalam memperpanjang umur simpan makanan melalui teknologi kemasan aktif berdasarkan aktivitas antibakterinya.
\end{abstract}

Kata kunci : Aktivitas antibakteri, Kemasan aktif, Minyak atsiri, Rempah

\begin{abstract}
CHEMICAL COMPOSITION, ANTIBACTERIAL ACTIVITIES, AND THE POTENCY FOR ACTIVE PACKAGING OF SOME ESSENTIAL OILS FROM INDONESIAN SPICES. This study aims to determine the chemical composition and antibacterial activity of 6 types of Indonesian essential oils. These essential oils are coriander oil, clove bud oil, lemongrass oil, kaffir lime oil, cinnamon oil, and cardamom oil. The study was conducted in two stages, characterization of essential oils using Gas Chromatography Mass Spectrometer (GC-MS) and determination of the antibacterial activity of each essential oil with gram-positive bacteria Staphylococcus aureus NBRC 100910 and gram-negative bacteria Escherichia coli NBRC 3301.Antibacterial activity was expressed as the diameter of the inhibition zone formed at the time of testing. Coriander oil, lemongrass oil and cinnamon oil have strong antibacterial activity against E. coli NBRC 330 and S.aureus NBRC 100910 with inhibition zone diameter in E. coli NBRC 330, $24 \mathrm{~mm}, 47 \mathrm{~mm}$ and $34 \mathrm{~mm}$ respectively; and in the S.aureus NBRC 100910 at 22 $\mathrm{mm}, 25 \mathrm{~mm}$ and $35 \mathrm{~mm}$, respectively. Clovebud oil has a moderate level of antibacterial activity at E. coli NBRC $330(19 \mathrm{~mm})$ and strong on S.aureus NBRC $100910(28 \mathrm{~cm})$. Cardamom oil showed moderate antibacterial activity against these two bacteria with an inhibition zone diameter of $14 \mathrm{~mm}$ for E. coli NBRC 330 and $12 \mathrm{~mm}$ for S.aureus NBRC 100910. Kaffir lime oil only has antibacterial activity against S.aureus NBRC 100910 with inhibition zone diameter of $22 \mathrm{~mm}$. Coriander oil, lemongrass oil, and cinnamon oil have the potential to be applied in extending the shelf life of food through active packaging technology based on their antibacterial activity.
\end{abstract}

Key words : Antibacterial activity, Active packaging, Essential oil, Spices 
Minyak atsiri telah digunakan sejak zaman dahulu sebagai wewangian dan pengobatan tradisional (Naeem et al. 2018). Seiring berjalannya waktu sejak abad sembilan belas, fungsi minyak atsiri selain sebagai perisa juga digunakan sebagai pengawetan makanan ( $\mathrm{M}$. Hyldgaard, Mygind, and Meyer 2012). Hal ini disebabkan adanya bioaktivitas dari minyak atsiri sebagai antibakteri, anti jamur, dan antioksidan. Aktivitas antibakteri dari minyak atsiri ini bergantung pada komposisi kimia yang terdapat di dalamnya dan jumlah masing-masing senyawa tersebut. Komposisi kimia, struktur, serta gugus fungsi senyawa dalam minyak atsiri memainkan peran penting dalam menentukan aktivitas antibakteri (Henri et al. 2012). Pemanfaatan minyak atsiri sebagai antibakteri dapat diaplikasikan secara langsung pada makanan, sebagai aditif untuk pengawet makanan maupun secara tidak langsung yaitu dengan teknologi kemasan aktif antimikroba yang merupakan salah satu sistem pengawetan makanan.

$\begin{array}{rrrr}\text { Penggunaan } & \text { minyak atsiri } & \text { sebagai } \\ \text { kemasan aktif } & \text { antimikroba } & \text { perlu }\end{array}$ mempertimbangkan aroma dari minyak atsiri tersebut karena aroma dapat bermigrasi pada makanan sehingga mempengaruhi sensori dari makanan tersebut (Arya et al. 2019) (Moshe Dvir et al. 2019) (Luca et al. 2016) (Hyldgaard, et al. 2012). Minyak atsiri dari tanaman rempah merupakan pilihan terbaik untuk dimanfaatkan dalam pengawetan makanan karena aromanya dapat diterima secara luas oleh konsumen (Macwan et al. 2016). Oleh karena itu perlu dipelajari kemampuan dari minyak atsiri berbasis rempah sebagai antibakteri serta komponen yang berperan dalam aktivitas tersebut, sehingga dapat digunakan sebagai pertimbangan untuk memilih jenis minyak atsiri yang akan digunakan dalam kemasan antimikroba.

Analisis aktivitas antibakteri dan komposisi kimia dari minyak atsiri tanaman rempah Indonesia pernah dilakukan pada minyak lime (lime oil), minyak lemon, minyak ceremai asam (eugenia oil), minyak adas, dan minyak spilanthes (Soetjipto, 2018) serta minyak bunga cengkeh (Gaylor et al. 2014), yang minyak atsirinya diproduksi sendiri di laboratorium. Pada penelitian ini penapisan aktivitas antibakteri dilakukan untuk 6 jenis minyak atsiri dari tanaman rempah Indonesia yang biasa digunakan sebagai bumbu masak. Minyak atsiri yang digunakan merupakan minyak atsiri komersil yang diproduksi melalui proses steam distillation dan telah memenuhi standar kualitas yang dipersyaratkan. Penentuan komposisi kimia dari masing-masing minyak atsiri tersebut dimaksudkan untuk mendapatkan hubungan antara komponen kimia dan aktivitas antibakteri dari masing-masing minyak atsiri. Minyak atsiri yang digunakan adalah minyak ketumbar, minyak bunga cengkeh, minyak sereh dapur, minyak kulit jeruk purut, minyak kayu manis, dan minyak kapulaga. Penelitian ini diharapkan dapat menjadi pertimbangan dalam memilih bahan antibakteri dari minyak atsiri yang nantinya dapat diaplikasikan dalam pengawetan makanan melalui sistem kemasan aktif.

\section{BAHAN DAN METODE}

\section{Bahan}

Minyak atsiri yaitu minyak ketumbar, minyak bunga cengkeh, minyak sereh dapur, minyak kulit jeruk purut, minyak kayu manis, dan minyak kapulaga yang berasal dari Nusaroma dan semuanya diproduksi dengan steam distillation. Bakteri uji yang digunakan adalah bakteri gram positif Staphylococcus aureus NBRC 100910 dan bakteri gram negatif Escherichia coli NBRC 3301. Gas Chromatography Mass Spectrometer (GC-MS) tipe GC 6890/MS 5975 MSD digunakan untuk karakterisasi minyak atsiri.

\section{Metode}

Karakterisasi komposisi komponen kimia minyak atsiri dengan Gas Chromatography Mass Spectrometer (GC-MS)

Identifikasi komponen kimia dalam minyak atsiri dilakukan menggunakan GC-MS (GC 6890/MS 5975 MSD) pada kolom kapiler HP5MS $(30 \mathrm{~m} \times 0,25 \mathrm{~mm} \times 0,25 \mu \mathrm{m})$. Kondisi oven diatur pada suhu awal $60{ }^{\circ} \mathrm{C}$ dan kemudian secara bertahap ditingkatkan pada kecepatan 3 ${ }^{\circ} \mathrm{C} /$ menit hingga $240{ }^{\circ} \mathrm{C}$. Helium digunakan sebagai gas pembawa dengan tekanan konstan pada $65 \mathrm{kPa}$. Minyak atsiri dinjeksikan dengan volume $1 \mu \mathrm{L}$ dengan mode split ratio 1:25. Metode ini mengacu pada karakteriksasi minyak atsiri yang dilakukan oleh Aidha dkk (Aidha et al. 2020).

\section{Uji aktivitas antibakteri}

Uji aktivitas antibakteri dilakukan dengan menggunakan metode difusi cakram kertas (Handayani et al. 2019). Agar Mueller Hinton digunakan sebagai media dengan bakteri uji Staphylococcus aureus NBRC 100910 dan bakteri gram negatif Escherichia coli NBRC 3301. Media agar Muller Hinton dibuat dengan menuangkan $10 \mathrm{~mL}$ media cair ke dalam cawan Petri steril (diameter $=90 \mathrm{~mm}$ ) dan dibiarkan mengeras selama 5 menit. Setelah itu $10 \mu \mathrm{l}$ kultur bakteri dengan konsentrasi $10^{-6} \mathrm{CFU} / \mathrm{mL}$ 
dituangkan ke atas media cair tadi dan dibiarkan mengering selama 5 menit. Kontrol negatif (akuades steril), kontrol positif (tetrasiklin $15 \mu \mathrm{g} / \mathrm{mL}$ ), dan sampel minyak atsiri dimasukkan ke dalam cakram kertas berdiameter $6 \mathrm{~mm}$ dengan volume masingmasing $10 \mu \mathrm{L}$. Cakram kertas tersebut kemudian diletakkan di atas permukaan media dan diinkubasi pada suhu $32^{\circ} \mathrm{C}$ selama 18 jam. Setelah inkubasi berakhir, terbentuk zona bening (zona hambat) di sekitar cakram kertas. Setiap percobaan dilakukan dalam tiga kali ulangan dan diameter zona hambat diukur.

\section{HASIL DAN PEMBAHASAN}

\section{Komponen kimia minyak atsiri}

Profil kromatografi dari masing-masing minyak atsiri yang diperoleh dari analisis menggunakan GC-MS dapat dilihat pada Gambar 1. Puncak-puncak yang ada dalam kromatogram menunjukkan keberadaan senyawa kimia yang telah dipisah-pisahkan dalam sistem GC-MS. Senyawa kimia ini kemudian diidentifikasi dengan mencocokkan pola fragmentasi spektrum massa dan membandingkan hasil spektrum massa dengan database yang ada dalam GC-MS (Wiley 7). Komposisi senyawa kimia dari masing-masing minyak atsiri yang diperoleh dari analisis menggunakan GC-MS dirangkum dalam Tabel 1.

Pada kromatogram minyak ketumbar terdapat 4 puncak tertinggi yang mengindikasikan adanya 4 jenis senyawa kimia, yaitu $y$ terpinene $(5,80 \%)$, m-cymene $(12,81 \%)$, linalool $(71,44 \%)$, dan champor $(9,96 \%)$. $Y$ terpinene, dan m-cymene termasuk dalam golongan monoterpena hidrokarbon. Linalool merupakan alkohol terpena yang banyak dijumpai pada minyak atsiri yang berasal dari bunga dan rempah. Linalool ini merupakan jenis senyawa dengan kelimpahan terbesar pada minyak ketumbar. Camphor merupakan terpenoid dengan gugus aldehida. Komponen senyawa kimia dalam minyak ketumbar biasanya terdiri atas 4 golongan senyawa, yaitu golongan alkohol (linalool, geraniol, terpineol), hidrokarbon ( $y$ terpinene, limonene), keton (camphor), dan ester (geranyl acetate, linalyl acetate) (Mandal and Mandal, 2015). Senyawa golongan ester tidak dijumpai dalam minyak ketumbar yang digunakan dalam penelitian ini. Beberapa faktor yang mempengaruhi komposisi senyawa kimia dalam minyak atsiri seperti interaksi dengan lingkungan (jenis tanah dan iklim), tingkat kematangan tanaman yang bersangkutan (Dhifi et al. 2016) (Akhtar, 2014) serta faktor ekstrinsik yang terkait dengan metode ekstraksi (Dhifi et al. 2016) (ReyesJurado et al. 2015)
Eugenol, $\beta$ caryophyllene, dan $\alpha$ humulene terdapat pada minyak bunga cengkeh dengan kelimpahan masing-masing sebesar $85,22 \%$, 10,89\%, dan 3,89\%. Eugenol (2-metoksi-4fenol), termasuk dalam golongan fenilpropanoid, merupakan turunan guaiakol yang mendapat tambahan rantai alil, sehingga dapat dikelompokkan dalam alilbenzena dari senyawasenyawa fenol. Eugenol merupakan komponen utama dari minyak bunga cengkeh yang menjadi parameter dalam penentuan kualitas dari minyak bunga cengkeh.

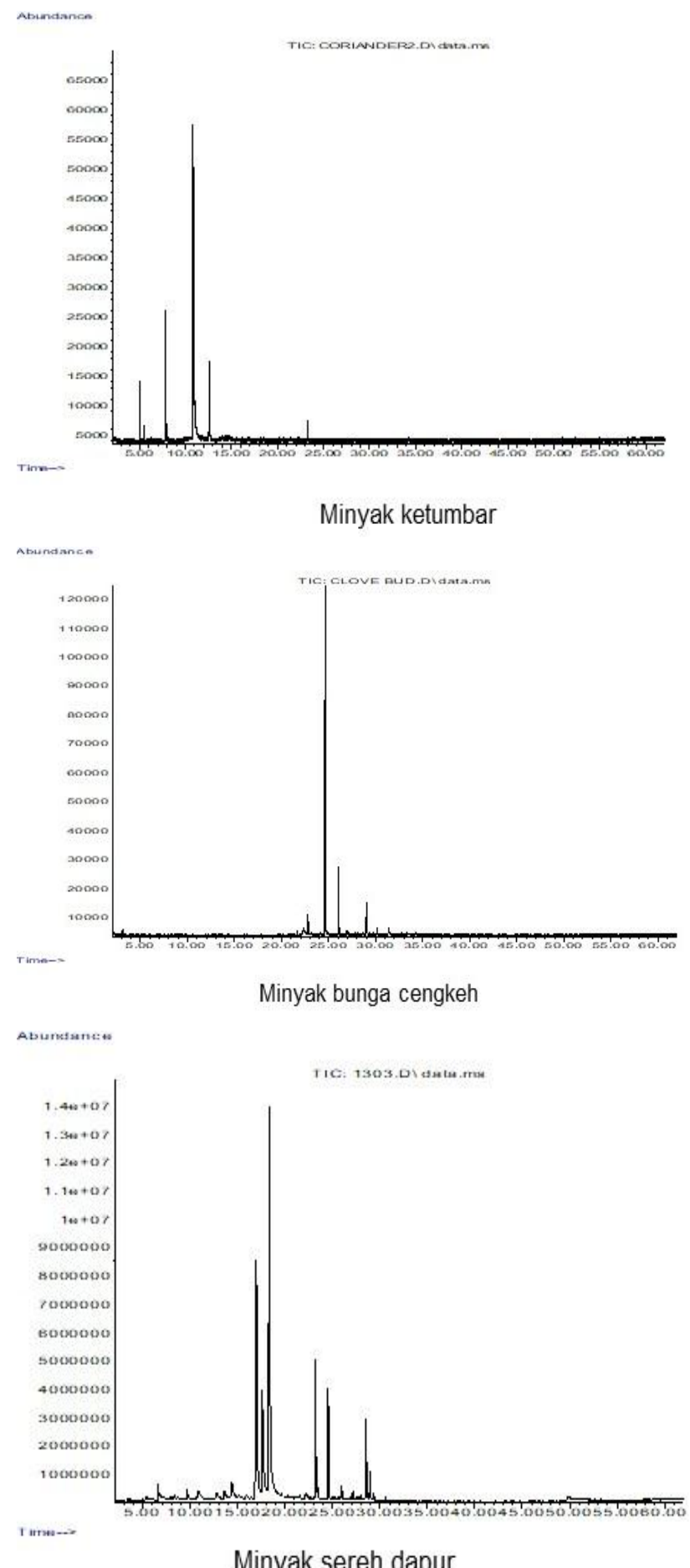



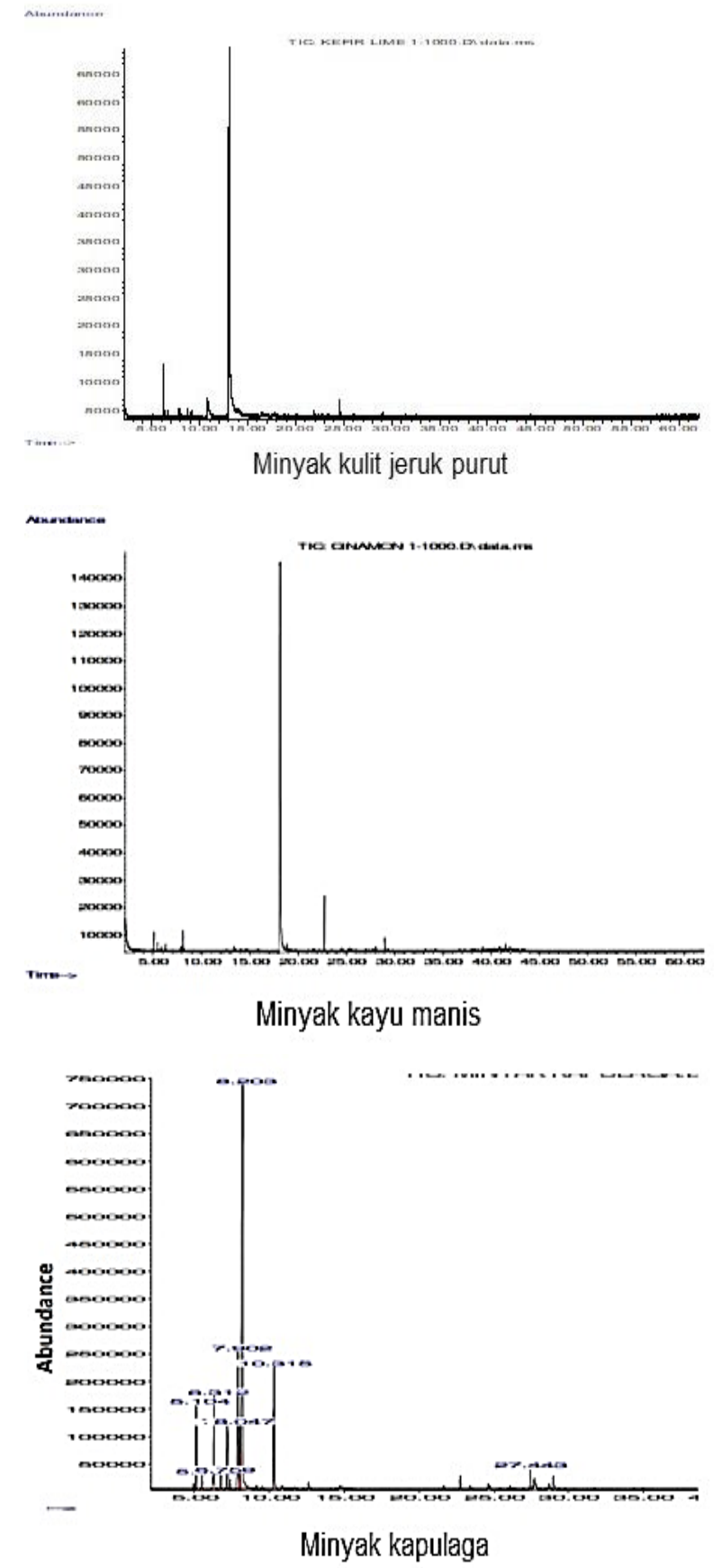

Gambar 1. Profil kromatogram dari minyak ketumbar, minyak bunga cengkeh, minyak sereh dapur, minyak kulit jeruk purut, minyak kayu manis, dan minyak kapulaga

Tabel 1. Komposisi kimia minyak atsiri

\begin{tabular}{lllr}
\hline No. & \multicolumn{1}{c}{$\begin{array}{c}\text { Jenis } \\
\text { minyak atsiri }\end{array}$} & \multicolumn{2}{c}{ Komponen kimia } \\
\cline { 3 - 4 } & & Nama senyawa & $\begin{array}{c}\text { Kelimpahan } \\
(\%)\end{array}$ \\
\hline \multirow{2}{*}{ 1. } & Minyak & $Y$-terpinene & 5,80 \\
& ketumbar & m-cymene & 12,81 \\
& & Linalool & 71.44 \\
& & Camphor & 9,96
\end{tabular}

2. Minyak Eugenol 85,22 bunga $\quad \beta$ caryophylene 10,89 cengkeh $\quad \alpha$ humulene 3,89

3. Minyak Iso-thujone 6,13 sereh dapur Neral (Z citral) 26,21 Cis geraniol $\quad 15,65$ Geranial $\quad 40,00$

(E c itral) Neryl acetate $\quad 1,74$

Trans farnesol $\quad 1,88$

$\beta$-caryophyllene $\quad 4,97$ $\gamma$-cadinene $\quad 3,45$

4. Minyak kulit Sabinen 4,56 jeruk purut D-limonene 5,60 Citronellal $\quad 89,84$

5. Minyak kayu 1,8 cineole 1,42 manis Cinnamaldehyde 81,30 Isobornyl 4,34 Cinnamaldehyde $\quad 7,00$ dimethyl acetal
$\beta$-caryophyllene Trans cinnamyl $\quad 3,90$ acetate

6. Minyak Sabinene 1,5 kapulaga $\quad \beta$ pinene $\quad 7,13$ p-cymene $\quad 1,10$ Limonene $\quad 5,78$ 1,8 cineole $\quad 54,98$ a terpenyl 20,60 acetate Linalyl acetate

Minyak sereh dapur mengandung beberapa macam senyawa kimia, diantaranya iso-thujone, neral ( $Z$ citral), cis geraniol, geranial ( $\mathrm{E}$ citral), neryl acetate, trans farnesol, $\beta$ caryophyllene, dan $\gamma$-cadinene. Minyak sereh dapur disebut juga lemongrass oil karena minyak ini memiliki aroma seperti lemon yang dihasilkan oleh senyawa citral. Citral (3,7dymethyl-2,6- octadienal) merupakan komponen utama dalam minyak sereh wangi, terdapat dalam 2 isomer, yaitu $Z$ citral (neral) dan $E$ citral (geranial) (Phunpee et al. 2017) (Majewska et al. 2019). Citral termasuk kelompok terpenoid dengan gugus aldehida. Citral yang terkandung dalam minyak sereh dapur ini sebesar 66,21\%. Geraniol merupakan komponen terbesar kedua dalam minyak sereh dapur, dijumpai dengan kelimpahan 15,65\%. Geraniol (3,7-dymethylocta-trans-2,6-dien-1-ol) memiliki struktur yang hampir sama dengan citral, termasuk kelompok terpenoid juga namun dengan gugus alkohol.

Komponen kimia yang teridentifikasi dalam minyak kulit jeruk purut adalah sabinene, $D$ limonene, dan citronellal dengan kelimpahan 
sebesar 4,56\%, 5,60\%, dan 95,44\%. Sabinene dan limonene merupakan kelompok senyawa monoterpena, sedangkan citronellal termasuk dalam kelompok terpenoid dengan gugus aldehida. Citronellal merupakan komponen utama dalam minyak kulit jeruk purut.

Minyak kayu manis mengandung beberapa macam komponen kimia yang teridentifikasi menggunakan GC-MS, yaitu 1,8 cineole, cinnamaldehyde, isobornyl acetate, cinnamaldehyde dimethyl acetal, $\beta$ caryophyllene, dan trans cinnamyl acetate dengan kelimpahan masing-masing dapat dilihat pada Tabel 1. Komponen utama dalam minyak kayu manis adalah cinnamaldehyde dengan kelimpahan $81,30 \%$, seperti dalam studi-studi sebelumnya (Gotmare and Tambe, 2019) (Cahyaningtyas et al. 2020). Cinnamaldehyde termasuk dalam kelompok fenilpropanoid dengan gugus aldehida dan ikatan rangkap terkonjugasi di luar cincin benzena.

Minyak kapulaga mengandung 1,8 cineole dan $\alpha$ terpenyl acetate sebagai dua komponen terbesarnya yang kelimpahannya $54,98 \%$ dan $20,60 \%$. Senyawa 1,8 cineole dan $\alpha$ terpenyl acetate merupakan senyawa penting yang berperan sebagai pemberi aroma dan parameter kualitas dari minyak kapulaga (Fathy and Morsy, 2017). Senyawa 1,8-sineol (1,3,3-trimethyl-2oxabicyclo [2.2.2] octane) yang merupakan komponen utama minyak kapulaga (Noumi et al. 2018) adalah eter siklik dengan rumus empiris $\mathrm{C}_{10} \mathrm{H}_{18} \mathrm{O}$ dan termasuk ke dalam golongan terpenoid. $\alpha$ - terpenyl acetate juga merupakan golongan terpenoid, namun dengan gugus ester.

\section{Aktivitas Antibakteri}

Aktivitas antibakteri dari minyak atsiri berhubungan erat dengan komponen yang terkandung di dalam minyak atsiri tersebut. Terpenoid (terpena teroksigenasi) menunjukkan aktivitas antibakteri yang kuat, sementara turunan terpena hidrokarbon memiliki sifat antibakteri yang lebih rendah, karena kelarutan airnya yang sangat rendah membatasi difusi mereka melalui media (Macwan et al. 2016). Minyak atsiri yang mengandung senyawa dengan gugus alkohol, aldehida, fenol, dan ester diketahui memiliki kemampuan sebagai antibakteri. Minyak atsiri yang mengandung aldehida atau fenol, seperti cinnamaldehyde, citral, carvacrol, eugenol atau thymol sebagai komponen utama menunjukkan aktivitas antibakteri tertinggi, diikuti oleh minyak atsiri yang mengandung alkohol terpena. Minyak atsiri lain yang mengandung keton atau ester, seperti $\beta$-myrcene, $\alpha$-thujone atau geranyl acetate memiliki aktivitas yang jauh lebih lemah. Minyak atsiri yang mengandung hidrokarbon terpena biasanya tidak aktif (Henri et al. 2012). Di sisi lain, karakter lipofilik dari kerangka hidrokarbon minyak atsiri dan karakter hidrofilik dari kelompok fungsionalnya penting dalam aksi antimikroba dari komponen minyak atsiri. Oleh karena itu, peringkat aktivitas telah diteliti dan menunjukkan bahwa gugus fenol > aldehida > keton $>$ alcohol $>$ ester $>$ hidrokarbon dalam hal aktivitas antimikroba (Kalemba and Kunicka, 2003). Aktivitas antibakteri dari minyak atsiri selain dipengaruhi oleh jenis gugus dalam komponen kimianya, dipengaruhi juga oleh sinergi dari komponen-komponen kimia yang ada di dalamnya.

Aktivitas antibakteri diuji dengan metode difusi cakram kertas menggunakan bakteri uji $S$. aureus NBRC 100910 yang mewakili bakteri gram positif dan E. coli NBRC 3301 yang mewakili bakteri gram negatif. Kedua jenis bakteri ini merupakan bakteri yang sering dikaitkan pada kontaminasi dan penyebab kerusakan makanan (Samira and Abbasipour, 2017). Metode difusi adalah pendekatan yang sudah sangat umum untuk skrining efektivitas antimikroba minyak atsiri atau kerentanan suatu strain bakteri terhadap minyak atsiri. Cakram kertas berukuran diameter $6 \mathrm{~mm}$ yang mengandung bahan antimikroba pada konsentrasi yang diinginkan ditempatkan di atas agar yang sudah disebar dengan bakteri uji, kemudian diinkubasi. Aktivitas antimikroba diamati secara visual dengan mengukur diameter zona hambatan yang mengelilingi masing-masing cakram kertas. Efek penghambatan yang lebih kuat dari bahan yang diuji menghasilkan diameter yang lebih luas (zona hambat yang lebih besar) atau tanpa pertumbuhan bakteri, sedangkan efek penghambatan yang lebih lemah atau tidak ada, maka zona hambat tidak ada atau tidak ada perubahan konsentrasi bakteri uji di sekitarnya (Rao et al. 2019). Aktivitas antimikroba yang mengacu pada metode tersebut berdasarkan diameter zona hambatnya dapat dikategorikan zona hambat kuat (diameter $\geq 20 \mathrm{~mm}$ ), zona hambat sedang/ringan $(12 \mathrm{~mm}<$ diameter $<20$ $\mathrm{mm}$ ), dan tidak ada zona hambat (diameter $<12$ $\mathrm{mm}$ ) (Rao et al. 2019)

Zona hambat yang dibentuk dari masingmasing jenis minyak atsiri pada uji difusi dapat dilihat pada Gambar 2. Pada gambar 2 memperlihatkan hasil inkubasi bakteri uji dengan minyak atsiri yang menghasilkan zona hambatan di sekeliling cakram kertas bila ada efek penghambatan oleh minyak atsiri terhadap bakteri uji. Cakram kertas dengan kode A merupakan cakram kertas yang berisi kontrol positif (tetrasiklin), kode B menyatakan minyak atsiri dan kode C menyatakan kontrol negatif (akuades). Kontrol positif merupakan bahan yang sudah diketahui sebagai antibakteri, digunakan untuk memastikan bahwa prosedur uji antimikroba yang dilakukan sudah benar. Besar diameter zona hambat yang terbentuk 
oleh masing-masing minyak atsiri selengkapnya
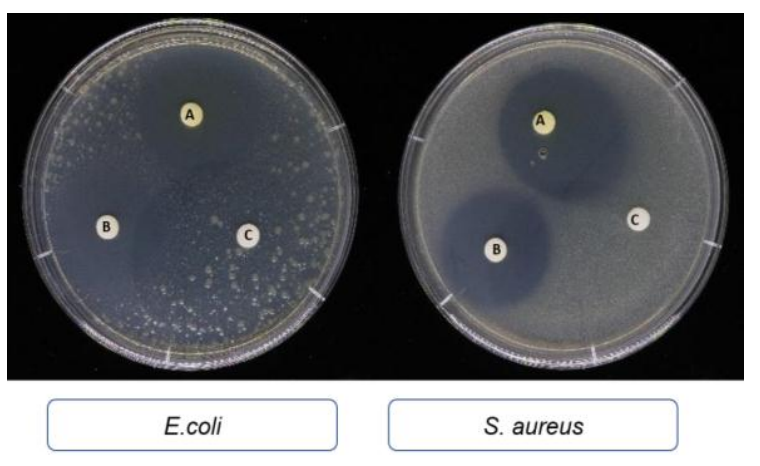

Minyak ketumbar

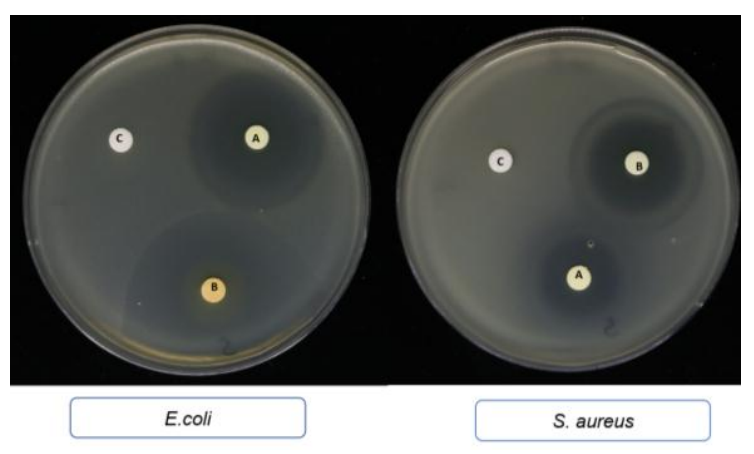

Minyak sereh dapur
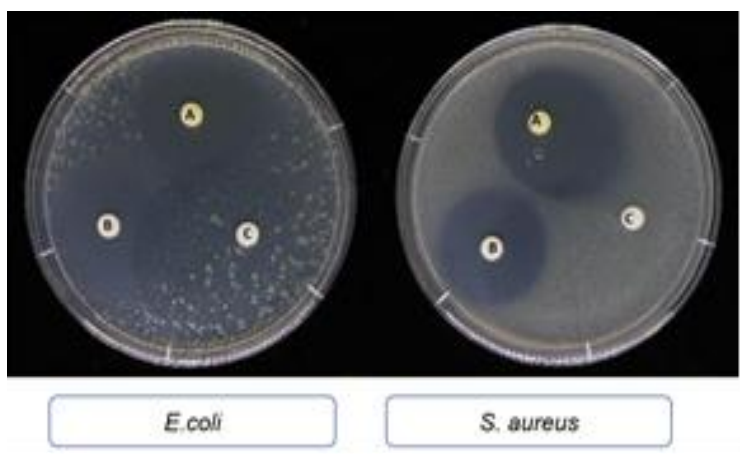

Minyak kayu manis dirangkum dalam Tabel 2.

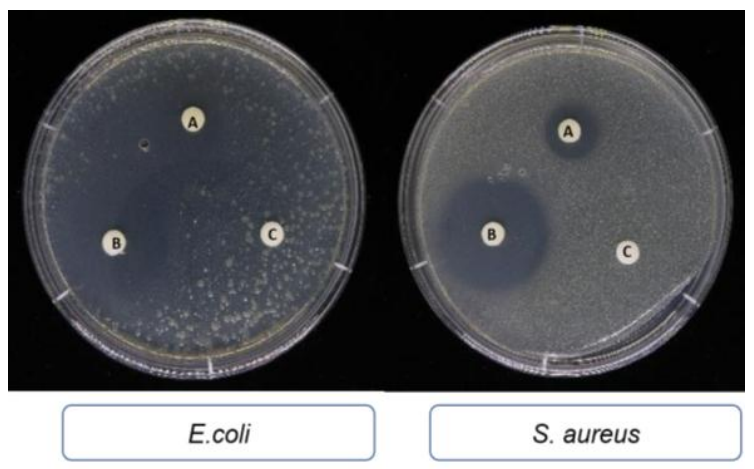

Minyak bunga cengkeh

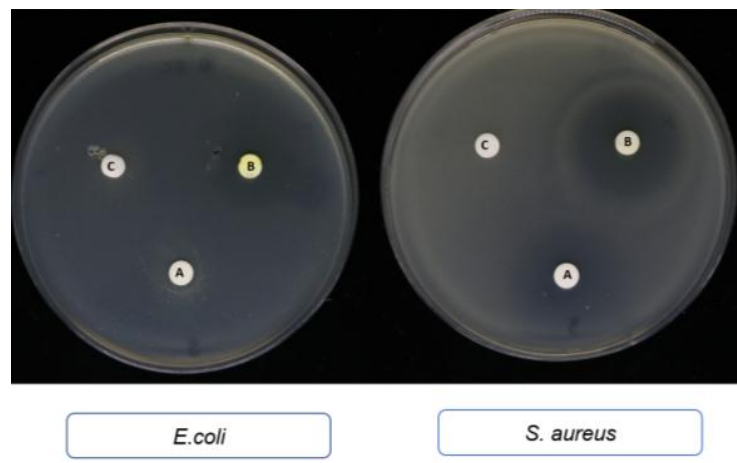

Minyak kulit jeruk purut

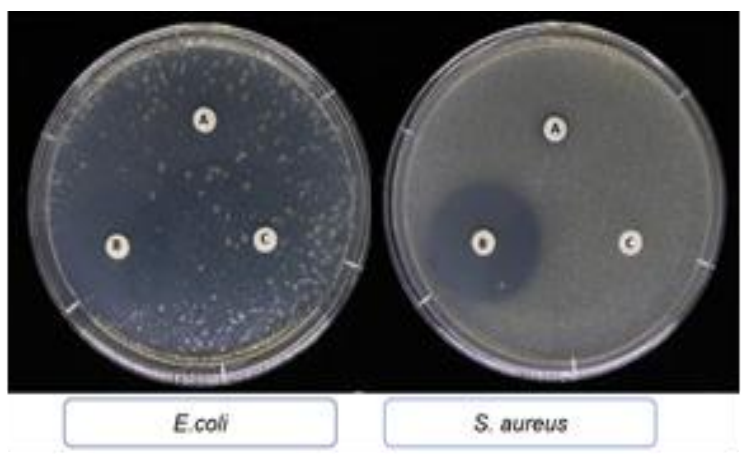

Minyak kapulaga

Gambar 2. Hasil penapisan aktivitas aktibakteri dari enam jenis minyak atsiri terhadap bakteri E. coli NBRC 3301 dan S. aureus NBRC 100910 (A: kontrol + (tetrasiklin), B: sampel (minyak atsiri) dan C: kontrol - (akuades))

Tabel 2. Hasil pengukuran diameter zona hambat pada penapisan Aktivitas antibakteri

\begin{tabular}{|c|c|c|c|c|c|c|c|c|c|}
\hline \multirow[t]{3}{*}{ No. } & \multirow[t]{3}{*}{ Jenis } & \multicolumn{4}{|c|}{ E. coli NBRC 3301} & \multicolumn{4}{|c|}{ S. aureus NBRC 100910} \\
\hline & & \multicolumn{3}{|c|}{ Diameter zona hambat (mm) } & \multirow[t]{2}{*}{ Kekuatan } & \multicolumn{3}{|c|}{ Diameter zona hambat (mm) } & \multirow[t]{2}{*}{ Kekuatan } \\
\hline & & Sampel & Kontrol - & Kontrol + & & Sampel & Kontrol - & Kontrol + & \\
\hline 1. & $\begin{array}{l}\text { Minyak } \\
\text { ketumbar }\end{array}$ & 24 & 0 & 30 & Kuat & 22 & 0 & 30 & Kuat \\
\hline 2. & $\begin{array}{l}\text { Minyak bunga } \\
\text { cengkeh }\end{array}$ & 19 & 0 & 30 & Sedang & 28 & 0 & 30 & Kuat \\
\hline 3. & $\begin{array}{l}\text { Minyak sereh } \\
\text { dapur }\end{array}$ & 47 & 0 & 20 & Kuat & 25 & 0 & 31 & Kuat \\
\hline 4. & $\begin{array}{l}\text { Minyak kulit } \\
\text { jeruk purut }\end{array}$ & 7 & 0 & 22 & $\begin{array}{c}\text { Lemah/tidak } \\
\text { ada }\end{array}$ & 22 & 0 & 36 & Kuat \\
\hline 5. & $\begin{array}{l}\text { Minyak kayu } \\
\text { manis }\end{array}$ & 34 & 0 & 30 & Kuat & 35 & 0 & 38 & Kuat \\
\hline 6. & $\begin{array}{l}\text { Minyak } \\
\text { kapulaga }\end{array}$ & 14 & 0 & 35 & Sedang & 12 & 0 & 37 & Sedang \\
\hline
\end{tabular}


Minyak ketumbar memiliki zona hambat baik terhadap E. coli NBRC 3301 maupun $S$. aureus NBRC 100910 dengan diameter zona hambatan sebesar $24 \mathrm{~mm}$ dan $22 \mathrm{~mm}$ sehingga digolongkan sebagai zona hambat yang kuat. Pada penelitian lain disebutkan bahwa minyak ketumbar dapat menghambat pertumbuhan E.coli NBRC 3301 menggunakan metode uji yang sama dengan penelitian ini, dengan diameter zona hambatan sebesar $25 \mathrm{~mm}$ (Mandal and Mandal, 2015) Linalool yang termasuk dalam kelompok monoterpen alkohol dan camphor yang merupakan golongan terpenoid dengan gugus keton adalah komponen-komponen yang berperan dalam aktivitas antibakteri ini.

Minyak bunga cengkeh menunjukkan zona hambatan yang lebih besar pada $S$. aureus NBRC 100910 dibanding pada E. coli NBRC 3301. Secara umum bakteri gram negatif lebih resisten terhadap minyak atsiri dibanding bakteri gram positif (Nazzaro et al. 2013). Bakteri gramnegatif memiliki membran luar yang rigid, kaya lipopolisakarida dan lebih kompleks sehingga membatasi difusi senyawa hidrofobik ke dalam. Membran yang sangat kompleks ini tidak ada pada bakteri Gram-positif namun ada dinding peptidoglikan yang tidak cukup padat sehingga tidak mampu menahan molekul antimikroba yang berukuran kecil dan memfasilitasi akses ke dalam membran sel. Selain itu bakteri gram positif dapat memudahkan infiltrasi senyawa hidrofobik seperti minyak atsiri karena adanya ujung lipofilik lipoteichoic acid yang ada di dalam membran sel (Chouhan et al. 2017). Eugenol yang merupakan komponen utama berperan dalam aktivitas antibakteri ini. Gugus hidroksil bebas pada eugenol dapat berikatan dengan protein yang berperan dalam sintesis enzim dalam membran sel bakteri (Marchese et al. 2017). Beberapa penelitian menyatakan bahwa minyak bunga cengkeh menunjukkan aktivitas antimikroba terhadap beberapa bakteri gram positif, bakteri gram negatif, jamur, serta menunjukkan aktivitas antioksidan (Cordery et al. 2018).

Berbeda dengan minyak bunga cengkeh yang aktivitas antibakterinya lebih besar terhadap $S$. aureus NBRC 100910, minyak sereh dapur memiliki aktivitas antibakteri yang lebih besar terhadap E. coli NBRC 3301, namun kekuatan daya hambatnya sama-sama digolongkan kuat untuk kedua jenis bakteri tersebut. Meskipun bakteri gram negatif lebih resisten terhadap minyak atsiri, namun pada uji penapisan menggunakan minyak sereh dapur menunjukkan bahwa bakteri gram positif $S$. aureus NBRC 100910 lebih tahan terhadap minyak atsiri (zona hambat yang terbentuk lebih kecil). Hal ini dapat disebabkan karena selain dipengaruhi jenis bakteri, aktivitas antibakteri juga dipengaruhi jenis komponen yang ada di dalamnya. Citral banyak berperan pada bioaktivitas minyak sereh dapur seperti antibakteri (Ganjewala, 2009) (Han Lyn and Nur Hanani, 2020) (Yang and Song, 2016) (Hosseinzadeh et al. 2020) (Majewska et al. 2019) dan antijamur (Ganjewala, 2009). Minyak sereh dapur memiliki aktivitas antibakteri terhadap bakteri gram positif dan bakteri gram negatif, baik dalam bentuk minyak maupun dalam bentuk uap (Argyropoulou et al. 2007) (Yunilawati et al. 2020). Geraniol dalam minyak sereh dapur juga dilaporkan memiliki aktivitas dalam melawan beberapa bakteri patogen (Ternus and Zanetti, 2015). (Hosseinzadeh et al. 2020) (Majewska et al. 2019) dan antijamur (Ganjewala, 2009).

Minyak kulit jeruk purut memiliki zona hambatan yang kuat pada $S$. aureus NBRC 100910 namun lemah/tidak ada pada $E$. coli NBRC 3301. Dalam penelitian lain disebutkan minyak kulit jeruk purut dapat menghambat pertumbuhan E.coli dan S.aureus (Sreepian et al. 2019). Tidak adanya aktivitas terhadap E. coli NBRC 3301 dalam penelitian ini dapat disebabkan beberapa faktor seperti konsentrasi minyak yang digunakan, jenis minyak yang digunakan, serta komponen yang ada dalam minyak kulit jeruk purut.

Minyak kayu manis menunjukkan zona hambatan pada $E$ coli NBRC 3301 maupun $S$. aureus NBRC 100910. dengan diameter zona hambatan yang tidak berbeda jauh (34 $\mathrm{mm}$ dan $35 \mathrm{~mm}$ ) dan dikategorikan kuat daya hambatnya. Hasil ini sama dengan penelitian yang telah dilakukan dalam menentukan Minimim Inhibitory Concentration/MIC (konsentrasi minimum yang dapat menghambat pertumbuhan bakteri) dari minyak kulit kayu manis dimana MIC untuk $E$. coli dan S.aureus memiliki nilai yang sama (Zhang et al. 2016). Dalam penelitian lain aktivitas antibakteri dari minyak kayu manis lebih besar terhadap S.aureus (Huang et al. 2014). Cinnamaldehyde yang merupakan komponen utama dari minyak kayu manis adalah senyawa fenilpropanoid dengan gugus aldehida dan berperan dalam aktivitas antibakteri ini (Berthold et al. 2019) (Zhang et al. 2016).

Minyak kapulaga menunjukkan zona hambatan, baik pada E. coli NBRC 3301 maupun S. aureus NBRC 100910 dengan tingkat kekuatan yang sedang dan besar diameter zona hambatan keduanya tidak berbeda jauh. Senyawa 1,8 cineol pada minyak kapulaga berperan dalam bioaktivitas sebagai antimikroba dan antioksidan (Bhavaniramya et al. 2019). Senyawa 1,8 cineol juga dapat bersinergi dengan limonene dalam aktivitasnya sebagai antibakteri (Chaleshtori et al. 2016)

Dari keseluruhan data penapisan antibakteri ini; minyak ketumbar, minyak sereh dapur dan minyak kayu manis memiliki aktivitas antimikroba yang kuat terhadap $E$. coli NBRC 
3301 dan S. aureus NBRC 100910. Minyak bunga cengkeh memiliki aktivitas antibakteri dengan tingkat sedang pada E. coli NBRC 330 dan kuat pada S.aureus NBRC 100910. Minyak kapulaga menunjukkan aktivitas antibakteri dengan tingkat sedang terhadap dua bakeri, sementara minyak kulit jeruk purut hanya memiliki aktivitas antibakteri terhadap $S$. aureus NBRC 100910 dengan tingkatan sedang. Dibandingkan dengan kontrol positif, hanya minyak sereh dapur yang memiliki zona hambatan lebih besar dibanding kontrol positif untuk uji pada bakteri gram negatif $E$. coli NBRC, sedangkan minyak yang lain zona hambatannya lebih kecil daripada kontrol positif. Minyak ketumbar, minyak sereh dapur dan minyak kayu manis berpotensi besar untuk digunakan sebagai bahan antibakteri pada kemasan aktif antibakteri untuk memperpanjang masa simpan makanan.

\section{KESIMPULAN}

Enam jenis minyak atsiri telah diidentifikasi komponen kimia penyusunnya menggunakan GC/MS. Enam jenis minyak atsiri tersebut memiliki komponen senyawa kimia yang beragam yang berperan sebagai antibakteri. Minyak sereh dapur, minyak ketumbar dan minyak kayu manis memiliki aktivitas antimikroba yang kuat baik pada $E$. coli NBRC 3301 maupun S. aureus NBRC 100910. Minyak kapulaga berada pada tingkatan sedang aktivitas antibakterinya terhadap E. coli NBRC 3301 dan S. aureus NBRC 100910. Minyak bunga cengkeh menunjukkan aktivitas antibakteri yang kuat pada $S$. aureus NBRC 100910 namun hanya pada tingkatan sedang pada E. coli NBRC 3301. Minyak kulit jeruk purut hanya memiliki aktivitas antibakteri terhadap $S$. aureus NBRC 100910. Dari enam jenis minyak atsiri tersebut, minyak ketumbar, minyak sereh dapur, dan minyak kayu manis berpotensi untuk diaplikasikan sebagai kemasan aktif antimikroba.

\section{UCAPAN TERIMAKASIH}

Penelitian ini didanai oleh Insentif Riset Sistem Inovasi Nasional (Insinas) dari Kementerian Riset dan Teknologi/Badan Riset dan Inovasi Nasional dengan Nomor Kontrak 32/INS-1/PPK/E4/2020 melalui mekanisme Kemiteraan antara Universitas Indonesia dan Balai Besar Kimia dan Kemasan (BBKK).

\section{DAFTAR PUSTAKA}

Aidha, N. N., R. Yunilawati, and I. Rumondang. 2020. "Method Development for Analysis of Essential Oils Authenticity Using Gas Chromatography-Mass Spectrometry
GC-MS )." In 2nd International Conference of Essential Oil Indonesia (ICEO), 41-46. https://doi.org/10.5220/000995600041004 6.

Akhtar, M. S. 2014. "Antimicrobial Activity of Essential Oils Extracted from Medicinal Plants Against The Pathogenic Microorganisms: A Review." Issues in Biological Sciences and Pharmaceutical Research, no. February.

Argyropoulou, C., D. Daferera, P. A. Tarantilis, C. Fasseas, and M. Polissiou. 2007. "Chemical Composition of The Essential Oil from Leaves of Lippia Citriodora H.B.K. (Verbenaceae) at Two Developmental Stages." Biochemical Systematics and Ecology $35 \quad$ (12): 831-37. https://doi.org/10.1016/j.bse.2007.07.001.

Arya, A., S. K. Mendiratta, R. K. Agarwal, S. K. Bharti, and P. Umarao. 2019. "Antimicrobial Profile and Organoleptic Acceptability of Some Essentials Oils and Their Blends in Hurdle Treated Chicken Meat Spread." International Journal of Current Microbiology and Applied Sciences 8 (09): 2162-77.

Berthold, A., P. Lidia, S. Różańska, A. Pluta, and M. Garbowska. 2019. "Antibacterial Activities of Plant-Derived Compounds and Essential Oils Against Cronobacter Strains." European Food Research and Technology $245 \quad$ (5): 1137-47. https://doi.org/10.1007/s00217-018-3218$\mathrm{x}$.

Bhavaniramya, S., S. Vishnupriya, M. S. Alaboody, R. Vijayakumar, and D. Baskaran. 2019. "Role of Essential Oils in Food Safety: Antimicrobial and Antioxidant Applications." Grain \& Oil Science and Technology. $\quad$ https://doi.org/10.1016/ j.gaost.2019.03.001.

Cahyaningtyas, A. A., R. Yunilawati, B. Amalia, W. Handayani, and C. Imawan. 2020. "Simple Antimicrobial Labels from Cinnamon Oil Added to Recycled Paper." Proceedings Ofthe 2nd International Conference of Essential Oils (ICEO 2019), no. Iceo 2019: 60-66. https://doi.org/ 10.5220/0009956300600066.

Chaleshtori, F. S., M. Taghizadeh, M. Rafieiankopaei, and R. Sharafati-chaleshtori. 2016. "Effect of Chitosan Incorporated with Cumin and Eucalyptus Essential Oils as Antimicrobial Agent on Fresh Chiken Meat." Journal of Food Processing and Preservation 40: 396-404. https://doi.org/10.1111/jfpp.12616.

Chouhan, S., K. Sharma, and S. Guleria. 2017. "Antimicrobial Activity of Some Essential Oils-Present Status and Future Perspectives." Medicines 4 (4): 58. 
https://doi.org/10.3390/medicines4030058

Cordery, A., A. P. Rao, and S. Ravishankar. 2018. "Antimicrobial Activities of Essential Oils , Plant Extracts and Their Applications in Foods- A Review." Journal of Agriculture and Environmental Sciences 7 (2): 76-89. https://doi.org/10.15640 /jns.v7n2a9.

Dhifi, W., S. Bellili, S. Jazi, N. Bahloul, and W. Mnif. 2016. "Essential Oils' Chemical Characterization and Investigation of Some Biological Activities: A Critical Review." Medicines 3 (4): 25. https://doi.org/10.3390/medicines3040025

Fathy, N., and S. Morsy. 2017. "Chemical Structure, Structure, Quality Chemical, Quality Indices, and Bioactivity Bioactivity of of Essential Oil Constituents Essential Oil Constituents." In Active Ingredient from Aromatic and Medical Plants, 175-206.

Ganjewala, D. 2009. "Cymbopogon Essential Oils: Chemical Compositions and Bioactivities." International Journal of Essential Oil Therapeutics 3: 56-65.

Gaylor, R., J. Michel, D. Thierry, R. Panja, F. Fanja, and D. Pascal. 2014. "Bud, Leaf, and Stem Essential Oil Composition of Syzygium Aromaticum from Madagascar, Indonesia and Zanzibar." International Journal of Basic and Applied Sciences 3 (3).https://doi.org/10.14419/ijbas.v3i3.2473.

Gotmare, B., and E. Tambe. 2019. "Identification of Chemical Constituents of Cinnamon Bark Oil by GCMS and Comparative Study Garnered from Five Different Countries." Global Journal of Science Frontier Research: C Biological Science 19 (1).

Han Lyn, F., and Z. A. Nur Hanani. 2020. "Effect of Lemongrass (Cymbopogon Citratus) Essential Oil on the Properties of Chitosan Films for Active Packaging." Journal of Packaging Technology and Research 4 (1): 33-44. https://doi.org/10.1007/s41783-01900081-w.

Handayani, W., R. Yunilawati, V. Fauzia, and C. Imawan. 2019. "Coriandrum Sativum I . ( Apiaceae ) and Elettaria Cardamomum ( I .) Maton ( Zingiberaceae ) for Antioxidant and Antimicrobial Protection Coriandrum Sativum I. ( Apiaceae ) and Elettaria Cardamomum ( I .) Maton ( Zingiberaceae ) for Antioxidant and Antimi." Journal of Physiscs: Conference Series. https://doi.org/10.1088/17426596/1317/1/012092.

Henri, I., N. Bassolé, and H. R. Juliani. 2012. "Essential Oils in Combination and Their Antimicrobial Properties." Molecules, 3989-4006. https://doi.org/10.3390/ molecules 17043989

Hosseinzadeh, S., R. Partovi, F. Talebi, and A. Babaei. $2020 . \quad$ "Chitosan/TiO2
Nanoparticle/Cymbopogon Citratus Essential Oil Film as Food Packaging Material: Physico-Mechanical Properties and Its Effects on Microbial, Chemical, and Organoleptic Quality of Minced Meat During Refrigeration." Journal of Food Processing and Preservation 44 (7): 1-12. https://doi.org/10.1111/jppp.14536.

Huang, D. F., J. G. Xu, J. X. Liu, H. Zhang, and Q. P. Hu. 2014. "Chemical Constituents, Antibacterial Activity and Mechanism of Action of The Essential Oil from Cinnamomum Cassia Bark Against Four Food-Related Bacteria." Microbiology (Russian Federation) 83 (4): 357-65. https://doi.org/10.1134/S002626171404006 7.

Hyldgaard, M., T. Mygind, and R. L. Meyer. 2012. "Essential Oils in Food Preservation: Mode of Action, Synergies , and Interactions with Food Matrix Components." Frontiers in Microbiology 3 (January): 1-24. https://doi.org/10.3389 /fmicb.2012.00012.

Hyldgaard, Morten, Tina Mygind, and Rikke Louise Meyer. 2012. "Essential Oils in Food Preservation: Mode of Action, Synergies, and Interactions with Food Matrix Components." Frontiers in Microbiology 3 (JAN): 1-24. https://doi.org/10.3389/fmicb.2012.00012.

Kalemba, D., and A. Kunicka. 2003. "Antibacterial and Antifungal Properties of Essential Oils." Current Medicinal Chemistry, 813-29.

Luca, A., U. Kidmose, I. Cavoski, and M. Edelenbos. 2016. "The Use of Antimicrobial Sachets in The Packaging of Organic Wild Rocket: Impact on Microorganisms and Sensory Quality." Postharvest Biology and Technology 121: 126-34. https://doi.org/10.1016/ j.postharvbio.2016.07.011.

Macwan, S. R., B. K. Dabhi, K. D. Aparnathi, and J. B. Prajapati. 2016. "Essential Oils of Herbs and Spices: Their Antimicrobial Activity and Application in Preservation of Food." International Journal of Current Microbiology and Applied Sciences 5 (5): 885-901. https://doi.org/10.20546/ijcmas. 2016.505.092.

Majewska, E., M. Kozlowska, E. GruczynskaSekowska, D. Kowalska, and K. Tarnowska. 2019. "Lemongrass (Cymbopogon Citratus) Essential Oil: Extraction, Composition, Bioactivity and Uses for Food Preservation - A Review." Polish Journal of Food and Nutrition Sciences $69 \quad$ (4): $\quad 327-41$. https://doi.org/10.31883/pjfns/113152.

Mandal, S., and M. Mandal. 2015. "Coriander (Coriandrum Sativum L.) Essential Oil: 
Chemistry and Biological Activity." Asian Pacific Journal of Tropical Biomedicine 5 (6): 421-28. https://doi.org/10.1016/j.apjtb. 2015.04.001.

Marchese, A., R. Barbieri, E. Coppo, I. Erdogan, and M. Daglia. 2017. "Antimicrobial Activity of Eugenol and Essential Oils Containing Eugenol: A Mechanistic Viewpoint" 43 (6): 668-89.

Moshe Dvir, I., O. Weizman, D. Lewitus, S. Weintraub, A. Ophir, and A. Dotan. 2019. "Antimicrobial Active Packaging Combining Essential Oils Mixture: Migration and Odor Control Study." Polymers for Advanced Technologies 30 (10): 2558-66. https://doi.org/10.1002/ pat.4642.

Naeem, A., T. Abbas, T. M. Ali, and A. Hasnain. 2018. "Essential Oils: Brief Background and Uses." Annals of Short Reports 1 (1): 1-3.

Nazzaro, F., F. Fratianni, L. De Martino, R. Coppola, and V. De Feo. 2013. "Effect of Essential Oils on Pathogenic Bacteria." Pharmaceuticals 6 (12): 1451-74. https://doi.org/10.3390/ph6121451.

Noumi, E., M. Snoussi, M. M. Alreshidi, P. D. Rekha, K. Saptami, L. Caputo, L. De Martino, et al. 2018. "Chemical and Biological Evaluation of Essential Oils from Cardamom Species." Molecules 23 (11). https://doi.org/10.3390/molecules23112818

Phunpee, S., U. Rangsadthong Ruktanonchai, H. Yoshii, S. Assabumrungrat, and A. Soottitantawat. 2017. "Encapsulation of Lemongrass Oil with Cyclodextrins by Spray Drying and Its Controlled Release Characteristics." Bioscience, Biotechnology and Biochemistry 81 (4): 718-23. https://doi.org/10.1080/09168451.2016.127 7942.

Rao, J., B. Chen, and D. J. McClements. 2019. "Improving the Efficacy of Essential Oils as Antimicrobials in Foods: Mechanisms of Action." Annual Review of Food Science and Technology 10 (1): 365-87. https://doi.org/10.1146/annurev-food032818-121727.

Reyes-Jurado, F., A. Franco-Vega, and N. Ramırez-Corona. 2015. "Essential Oils : Antimicrobial Activities, Extraction Methods, and Their Modeling." Food Eng Rev 7: 275-97. https://doi.org/10.1007/ s12393-014-9099-2.
Samira, G. C, and A. Habib. 2017. "Chemical Composition and Insecticidal Effects of The Essential Oil of Cardamom, Elettaria Cardamomum on the Tomato Leaf Miner, Tuta Absoluta." Toxin Reviews 36 (1): 12$17 . \quad$ https://doi.org/10.1080/15569543. 2016.1250100.

Soetjipto, H. 2018. "Antibacterial Properties of Essential Oil in Some Indonesian Herbs." Intechopen. https://doi.org/10.5772/ intechopen.78033.

Sreepian, A., P. M. Sreepian, C. Chanthong, T. Mingkhwancheep, and P. Prathit. 2019. "Antibacterial Activity of Essential Oil Extracted from Citrus Hystrix (Kaffir Lime) Peels: An in Vitro Study." Tropical Biomedicine 36 (2): 531-41.

Ternus, Z. R., and M. Zanetti. 2015. "Microbiological Characterization of Pure Geraniol and Comparison with Bactericidal Activity of the Cinnamic Acid in GramPositive and Gram-Negative Bacteria." Journal of Microbial \& Biochemical Technology $07 \quad$ (04): 186-93. https://doi.org/10.4172/19485948.1000203.

Yang, H. J., and K. B. Song. 2016. "Application of Lemongrass Oil-Containing Polylactic Acid Films to The Packaging of Pork Sausages." Korean Journal for Food Science of Animal Resources 36 (3): 421$26 . \quad \mathrm{https}: / /$ doi.org/10.5851/kosfa. 2016.36.3.421.

Yunilawati, R., W. Handayani, A. A. Cahyaningtyas, B. Amalia, and C. Imawan. 2020. "Antimicrobial Label from Lemongrass Oil Incorporated with Chitosan I Ascorbic Acid." In 2nd International Conference of Essential Oil Indonesia (ICEO), 147-52. https://doi.org/10.5220/ 0009968501470152.

Zhang, Y., X. Liu, Y. Wang, P. Jiang, and S. Y. Quek. 2016. "Antibacterial Activity and Mechanism of Cinnamon Essential Oil Against Escherichia Coli and Staphylococcus Aureus." Food Control 59: 282-89. https://doi.org/10.1016/j.foodcont. 2015.05.032. 